\title{
Effect of treatment time on performance of nano-encapsulated fluoride dentifrices for remineralization of initial carious lesions: an in vitro study
}

\author{
Andressa F.B. Oliveira', Elizabeth B.G. Sousa ${ }^{2}$, Nayanna L.S. Fernandes', Ingrid A. Meira ${ }^{4}$, \\ Juliane R. Lavôr ${ }^{3}$, Ana M.B.P. Chaves ${ }^{1}$, Fábio C. Sampaio ${ }^{5}$ \\ 1.Universidade Federal da Paraíba, Faculdade de Odontologia, Departamento de Morfologia, Disciplina de Histologia, \\ João Pessoa, Brasil. \\ 2. Universidade Federal da Paraíba, Faculdade de Odontologia, João Pessoa, Brasil. \\ 3. Universidade Federal da Paraíba, Faculdade de Odontologia, Programa de Pós-graduação en Odontologia, João \\ Pessoa, Brasil. \\ 4. Universidade de Campinas, Faculdade de Odontologia de Piracicaba, Programa de Pós-graduação en Clínica \\ Odontológica, Piracicaba, Brasil. \\ 5. Universidade Federal da Paraíba, Faculdade de Odontologia, Departamento de Clínica e Odontologia Social, Discipli- \\ na de Cariologia, João Pessoa, Brasil.
}

\begin{abstract}
The aim of this in vitro study was to evaluate the influence of treatment time on the remineralization performance of nanoencapsulated fluoride dentifrices on initial carious lesions. Ninety-six human enamel samples were allocated to eight groups $(n=12): 50 \% \mathrm{NanoF}+50 \%$ free NaF, $100 \% \mathrm{NanoF}$, $100 \% \mathrm{NaF}$ (positive control), and placebo (negative control), using two different treatment times (one and five minutes) for each dentifrice tested. After the carious lesion induction, the specimens were submitted to a $\mathrm{pH}$ remineralizing cycling model for seven days. Surface microhardness was measured before and after carious lesion induction and after treatment. The percentage of surface remineralization was calculated for each study time. Data were analyzed using two-way ANOVA and ANOVA repeated-measures tests followed by the
\end{abstract}

Bonferroni correction $(p<0.05)$. Remineralization differences were observed in the dentifrices analyzed according to the treatment time used. NanoF formulations with 50\% (one-min treatment) and $100 \%$ (five-min treatment) promoted significant remineralization of enamel after the caries challenge when compared to the placebo dentifrice $(p<0.05)$. Thus, time was considered an important factor for the fluoride release system. Nanotechnology can be a promising system for caries remineralization as it makes fluoride available on the dental surface for a longer time.

Received: October 2020; Accepted: January 2021.

Keywords: dental caries - fluorides - nanotechnology dentifrice.

\section{Efeito do tempo de tratamento no desempenho de dentifrícios de fluoreto nano- encapsulado para remineralização de lesões iniciais de cárie: um estudo in vitro}

\section{RESUMO}

O objetivo deste estudo in vitro foi de avaliar a influência do tempo de tratamento no desempenho de dentifrícios fluoretados nano-encapsulados na remineralização de lesões cariosas iniciais. Noventa e seis amostras de esmalte humano foram divididas em oito grupos $(n=12): 50 \% \mathrm{NanoF}+50 \% \mathrm{NaF}$ livre, $100 \%$ NanoF, 100\% NaF (controle positivo) e Placebo (controle negativo) com dois tempos diferentes (um e cinco minutos). Após a indução da lesão cariosa, os espécimes foram submetidos a um modelo de ciclagem de $\mathrm{pH}$ por sete dias. A microdureza superficial foi medida antes e após a indução da lesão cariosa e após o tratamento. O percentual de remineralização superficial foi calculado para cada tempo de estudo. Os dados foram analisados pelo ANOVA e ANOVA de medidas repetidas, seguida de Bonferroni $(p<0,05)$. Diferenças de remineralização foram observadas nos dentifrícios de acordo com o tempo de tratamento utilizado. Formulações NanoF com 50\% (tratamento de um minuto) e $100 \%$ (tratamento de cinco minutos) promoveram uma remineralização do esmalte, após o desafio cariogênico, quando comparado com o dentifrício placebo $(p<0,05)$. Assim, o tempo foi considerado um fator importante para o sistema de liberação de flúor. A nanotecnologia pode ser um sistema promissor de remineralização da cárie, por disponibilizar o flúor por maior tempo na superfície dentária.

Palavras-chave: cárie dentária - fluoretos - nanotecnologia dentifrícios. 


\section{INTRODUCTION}

Dental caries has multifactorial etiology involving exposure to acid due to bacterial metabolism ${ }^{1-3}$. It is the most prevalent oral health problem throughout the world, causing a considerable economic burden and a negative impact on quality of life ${ }^{2,4}$. As human enamel cannot be biologically repaired or replaced ${ }^{5}$, several studies have been conducted in search of means to protect it by improving techniques and products to ensure better prevention and remineralizing capacity ${ }^{6-9}$.

Fluoride is the main factor responsible for the decline in dental caries in recent decades ${ }^{10,11}$. Indeed, fluoride dentifrices are widely used and effective at delivering free or soluble fluoride to the oral cavity ${ }^{12}$.

Recent progress has been made in systems for promoting enamel remineralization ${ }^{6,9}$. In vitro studies have contributed to the understanding of the chemistry the incorporation of fluoride and its compatibility with the ingredients in dentifrices, and have tested new formulations and mechanisms of caries inhibition ${ }^{1,13}$. The anti-cariogenic role of fluoride has been $\operatorname{proven}^{11,14,15}$. Fluoridated hydroxyapatite $^{2}$ (mineral crystal of dental tissue) has greater chemical stability and therefore better protects the teeth against acid attacks from cariogenic bacteria and consequent demineralization ${ }^{1,2}$. Thus, local therapies using drug delivery systems have attracted considerable attention as a way to transport and release therapeutic agents or bioactive substances into the oral cavity ${ }^{16}$.

The use of nanotechnology has gained prominence in preventive dentistry as a slow-release system for substances that can control and treat oral problems ${ }^{17-21}$. Involving components less than 100 nanometers in $\operatorname{size}^{22}$, this technology may perform on the molecular level with greater affinity and effectiveness compared to micro or macro components ${ }^{18,23}$. In preventive dentistry, studies have reported better control of biofilm, prevention of caries, remineralization of initial carious lesions and sub-micrometric dental defects, biomimetic enamel synthesis and repair of microcavities ${ }^{17-20,23,24}$. The innovative idea of using nano-encapsulated fluorine ions (NanoF) in a controlled release system may be beneficial to enamel, as it would increase its substantivity and enable the substance to remain in contact with the dental surface for a longer time, leading to a greater protective and remineralizing effect. Therefore, the aim of the present study was to evaluate the influence of treatment time on the performance of nano-encapsulated fluoride (NanoF) dentifrices for the remineralization of initial carious lesions using an in vitro $\mathrm{pH}$ cycling model. The null hypothesis was that NanoF dentifrices have the same ability to remineralize dental caries as conventional $\mathrm{NaF}$, regardless of treatment time.

\section{MATERIALS AND METHODS}

This study received approval from a research ethics committee in Brazil (certificate number: 45917915.6.0000.5188). The donors of the teeth signed a statement of informed consent in accordance with the Declaration of Helsinki and Resolution 466/12 of the Brazilian National Health Board.

\section{Sample size and specimen preparation}

Sample size was determined considering remineralizing potential as the primary outcome. Based on a previous study ${ }^{25}$ and considering a twotailed alpha of 0.01 and $80 \%$ power, a minimum of seven samples was required per group. Ninety human third molars with indication for extraction were collected, cleaned, and examined for any enamel alterations.

Enamel blocks ( $3 \times 3 \times 2 \mathrm{~mm}$ ) were obtained from the dental crown (buccal and lingual surfaces) and embedded in self-curing acrylic resin using circular molds (16 x $3 \mathrm{~mm})$. A metallographic polisher was used to flatten the outer enamel (with 400, 600 and 1200 grit sandpaper disks) under constant irrigation. The enamel surfaces were polished with wet felt and a $1 \mu \mathrm{m}$ diamond suspension (Extec Corporation, Enfield, CT, USA) in a rotating polishing machine (PSK- 2V, Skill-Tec Comércio e Manutenção Ltda, São Paulo, SP, Brazil). All samples were submitted to water sonication for five minutes and stored at $-20^{\circ} \mathrm{C}$ until the day of the experiment.

A total 96 enamel specimens were randomly distributed into eight groups $(\mathrm{n}=12)$ according to their initial surface microhardness and time treatments: PC1'(dentifrice with $100 \% \mathrm{NaF}$ fluoride, 1 minute); PC5'(dentifrice with 100\% NaF fluoride, 5 minutes); NC1' (dentifrice without fluoride, 1 minute); NC5' (dentifrice without fluoride, 5 minutes); $50 \% \mathrm{nF} 1$ ' (dentifrice with $50 \% \mathrm{NanoF}+50 \% \mathrm{NaF}$ free, 1 minute); $50 \% \mathrm{nF} 5$ ' (dentifrice with $50 \% \mathrm{NanoF}+$ $50 \% \mathrm{NaF}$ free, 5 minutes); $100 \% \mathrm{nF} 1$ ' (dentifrice with $100 \%$ NanoF, 1 minute) and $100 \% \mathrm{nF} 5$, (dentifrice with 100\% NanoF, 5 minutes), coded by 
an independent researcher, as described in Table 1. Enamel surface microhardness was analyzed with a microhardness tester (Shimadzu HMV - AD Easy Test Version 3.0). Five indentations spaced $100 \mu \mathrm{m}$ from each other were made at the center of the enamel surface (Vickers, 100g, 10s). Firstly, a baseline measurement ( $\mathrm{SH} 0$ ) was performed, and then new measurements were taken after the formation of the carious lesion ( $\mathrm{SH} 1)$ and remineralizing treatment (SH2), using the same initial parameters. Enamel blocks with initial surface microhardness between 390 and 440 VHN were selected for the study.

\section{Induction of caries lesion}

Following the SH0 measurements, the enamel surface of each specimen was divided into three equal parts. One third of the exposed enamel was covered with a double layer of nail varnish (Risque, Niasi, Taboão da Serra, São Paulo, Brazil) to preserve a control area in each specimen. Subsurface enamel demineralization was induced in the other two thirds by immersing each enamel specimen in $32 \mathrm{ml}$ of demineralizing solution $[1.3 \mathrm{mM} / \mathrm{L}$ $\mathrm{Ca}\left(\mathrm{NO}_{3}\right)_{2} \cdot 4 \mathrm{H}_{2} \mathrm{O}, 0.78 \mathrm{mM} / \mathrm{L} \mathrm{NaH} \mathrm{PO}_{4} \mathrm{H}_{2} \mathrm{O}$ in 0.05 $\mathrm{M} / \mathrm{L}$ acetate buffer, $0.03 \mu \mathrm{gF} / \mathrm{mL}(\mathrm{NaF}), \mathrm{pH} 5.0]$ for $16 \mathrm{~h}$ at $37^{\circ} \mathrm{C}{ }^{26}$. Post-demineralization surface hardness $\left(\mathrm{SH}_{1}\right)$ was determined, and the percentage of surface hardness change (SMHC) was calculated $[\% \mathrm{SMHC}=(\mathrm{SH} 1-\mathrm{SH} 0 / \mathrm{SH} 0) \times 100]$.

\section{Collection of human saliva}

Stimulated human saliva was collected from 12 healthy individuals 18 to 35 years old, of both sexes, without system involvement and resident in a city without fluoridated water. Exclusion criteria were having used drugs that interfere in the salivary flow or fluoride products within the last four weeks; using orthodontic appliances; presence of caries and/or erosion lesions and/or periodontal disease. Stimulated human saliva was collected each day of the study. Each volunteer chewed paraffin wax and spat the stimulated saliva into a plastic cup. The samples were stored in a refrigerator at $5{ }^{\circ} \mathrm{C}$ until use $\mathrm{e}^{27}$.

\section{Remineralizing pH cycling}

Before the remineralization $\mathrm{pH}$ cycling model based on Vieira et al. ${ }^{28}$, another third of the surface of the enamel specimens was covered with two layers of nail varnish (Risque, Niasi, Taboão da Serra, São Paulo, Brazil), to provide a carious lesion reference area (SH1). In each cycling model (Fig 1), the specimens were submitted to a five-day ${ }^{28} \mathrm{pH}$ cycling model at $37^{\circ} \mathrm{C}$, and remained in the remineralizing solution for 2 days. The blocks were individually immersed in a remineralization solution (1.5 $\mathrm{mmol} / \mathrm{L} \mathrm{Ca}, 0.9 \mathrm{mmol} / \mathrm{LP}, 150 \mathrm{mmol} / \mathrm{L} \mathrm{KCl}, 0.05$ $\mathrm{mg} \mathrm{F} / \mathrm{mL}$ in $0.1 \mathrm{~mol} / \mathrm{L}$ Tris buffer, $\mathrm{pH} 7.0$ ) for 18 h. The cariogenic challenge was performed using a demineralizing solution $(0.05 \mathrm{~mol} / \mathrm{L}$ acetate buffer,

Table 1. Dentifrices used in the study according to their composition and manufacturer*.

\begin{tabular}{|c|c|c|c|}
\hline Group** & Time Treatment & Composition & Manufacturer $* \star \star$ \\
\hline $\begin{array}{c}\text { 50\%nF1 } \\
(50 \% \text { NanoF }+50 \% \text { NaF free })\end{array}$ & 1 minute & $\begin{array}{l}50 \% \mathrm{NanoF}+50 \% \mathrm{NaF} \\
\quad(1450 \mathrm{ppm} \text { fluoride })\end{array}$ & $\begin{array}{l}\text { SAVOY, Jundiaí, } \\
\text { São Paulo, Brazil }\end{array}$ \\
\hline $\begin{array}{c}\text { 50\%nF5' } \\
(50 \% \text { NanoF + 50\% NaF free })\end{array}$ & 5 minutes & $\begin{array}{l}50 \% \mathrm{NanoF}+50 \% \mathrm{NaF} \\
\quad(1450 \mathrm{ppm} \text { fluoride })\end{array}$ & $\begin{array}{l}\text { SAVOY, Jundiaí, } \\
\text { São Paulo, Brazil }\end{array}$ \\
\hline $\begin{array}{c}100 \% \text { nF } 1^{\prime} \\
(100 \% \text { NanoF })\end{array}$ & 1 minute & $\begin{array}{c}100 \% \text { NanoF } \\
\text { (1450 ppm fluoride) }\end{array}$ & $\begin{array}{l}\text { SAVOY, Jundiaí, } \\
\text { São Paulo, Brazil }\end{array}$ \\
\hline $\begin{array}{c}100 \% \text { nF1' } \\
(100 \% \text { NanoF })\end{array}$ & 5 minutes & $\begin{array}{c}100 \% \text { NanoF } \\
\text { (1450 ppm fluoride) }\end{array}$ & $\begin{array}{l}\text { SAVOY, Jundiaí, } \\
\text { São Paulo, Brazil }\end{array}$ \\
\hline $\begin{array}{c}\text { PC1' } \\
\text { (Positive control - } 100 \% \mathrm{NaF})\end{array}$ & 1 minute & $\begin{array}{l}100 \% \text { sodium fluoride }-\mathrm{NaF}(1450 \\
\text { ppm fluoride) }\end{array}$ & $\begin{array}{l}\text { SAVOY, Jundiaí, } \\
\text { São Paulo, Brazil }\end{array}$ \\
\hline $\begin{array}{c}\text { PC5' } \\
\text { (Positive control - } 100 \% \mathrm{NaF} \text { ) }\end{array}$ & 5 minutes & $\begin{array}{l}100 \% \text { sodium fluoride }-\mathrm{NaF} \text { (1450 } \\
\text { ppm fluoride) }\end{array}$ & $\begin{array}{l}\text { SAVOY, Jundiaí, } \\
\text { São Paulo, Brazil }\end{array}$ \\
\hline $\begin{array}{c}\text { NC1' } \\
\text { (Negative control - no fluoride) }\end{array}$ & 1 minute & No fluoride & $\begin{array}{l}\text { SAVOY, Jundiaí, } \\
\text { São Paulo, Brazil }\end{array}$ \\
\hline $\begin{array}{c}\text { NC5' } \\
\text { (Negative control - no fluoride) }\end{array}$ & 5 minutes & No fluoride & $\begin{array}{l}\text { SAVOY, Jundiaí, } \\
\text { São Paulo, Brazil }\end{array}$ \\
\hline
\end{tabular}

*All experimental dentifrices included the following ingredients: water, carboxymethyl cellulose (binder), sodium lauryl sulfate (surfactant), hydrated silica (abrasive), 70\% sorbitol and glycerin (humectants), and methylparaben (preservative).

**1' - one-minute treatment and 5' - five-minute treatment.

${ }^{* \star *}$ The patent pending (BR 102018070679-9 A2) belongs to NANOVETORES TECNOLOGIA S.A. 


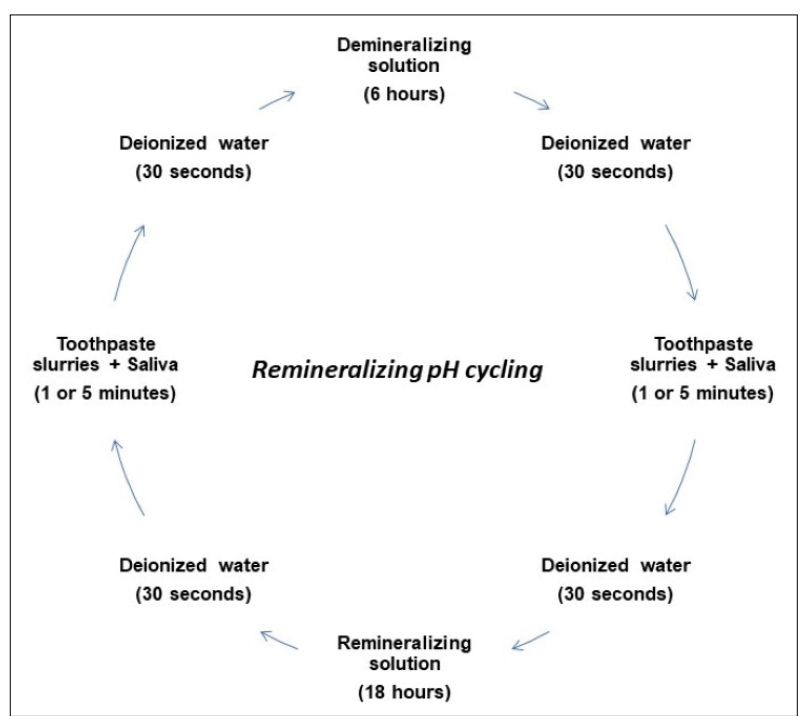

Fig. 1: Flow chart of the remineralizing $p H$ cycling model.

$\mathrm{pH} 5.0$, containing $1.28 \mathrm{mmol} / \mathrm{L} \mathrm{Ca}, 0.74 \mathrm{mmol} /$ $\mathrm{LP}$, and $0.03 \mathrm{mg} \mathrm{F} / \mathrm{mL}$ ) for six hours per day. The treatment regime consisted of immersing the enamel samples in dentifrice slurries twice a day $(1: 3 \mathrm{w} / \mathrm{w} ; 2$ $\mathrm{mL}$ /enamel specimen) for one or five minutes under agitation. The treatments were performed before and after the demineralizing solution. In order to activate the salivary amylase of the NanoF groups, a volume of approximately $10 \%$ of human saliva was added to all the dentifrice slurries. Samples were rinsed with deionized water between steps. The demineralizing and remineralizing solutions were refreshed every day. All eight groups were submitted to the same $\mathrm{pH}$ cycling, differing only in treatment times (one or five minutes). At the end of the seventh day of $\mathrm{pH}$ cycling, the specimens were washed again with deionized water under sonication for $5 \mathrm{~min}$ and stored in a humidity-controlled environment to prevent drying until further analysis.

After the remineralizing $\mathrm{pH}$-cycling, the nail varnish was removed and enamel surface microhardness was again determined $\left(\mathrm{SH}_{2}\right)$ as baseline parameters. The values were averaged $(\mu \mathrm{m})$ and the percentage surface microhardness recovery was calculated as following formula: $\% \mathrm{SMHR}=\left(\mathrm{SH}_{2}-\mathrm{SH}_{1}\right) /\left(\mathrm{SH}_{0}-\mathrm{SH}_{1}\right)$ $\times 100$.

\section{Statistical analysis}

Data were statistically analyzed using the SPSS, version 21.0 (SPSS, Inc., Chicago, IL, USA). Normal Distribution and homogeneity of variances were tested using the Shapiro-Wilk test and
Levine test, respectively. Since data demonstrated homogeneity of variances and Gaussian distribution, no data transformation was necessary. Assumptions of analysis of variance were checked before the use of two-way factorial analysis of variance (ANOVA) model to investigate surface microhardness remineralization in the different groups for the dependent variable $\left(\% \mathrm{SMH}_{\mathrm{R}}\right)$, and ANOVA Repeated Measures, followed by Bonferroni, to analyze the variables $\mathrm{SH}_{0}, \mathrm{SH}_{1}, \mathrm{SH}_{2}$ within the same group at the different analysis times. The level of significance considered was $5 \%(\mathrm{p}<0.05)$.

\section{RESULTS}

Table 2 shows the mean and standard deviation values for the variables $\mathrm{SH}_{0}, \mathrm{SH}_{1}$, and $\mathrm{SH}_{2}$ for all test groups. Comparison according to the variables $\mathrm{SH}_{0}, \mathrm{SH}_{1}$ and \% $\mathrm{SMHC}$ showed no difference between groups $(\mathrm{p}>0.05)$. However, for the $\mathrm{SH}_{2}$ variable, differences were observed between groups $(\mathrm{p}<0.001)$. The 5-minute $\mathrm{PC}$ had the best remineralization value and the $50 \% \mathrm{nF} 1,50 \% \mathrm{nF} 5$ ' and $100 \% \mathrm{nF} 5$ ' performed similarly to the 1-minute positive control.

Individual analysis of each dentifrice remineralization showed no significant difference between $\mathrm{SH}_{0}$ and $\mathrm{SH}_{1}$. However, there were differences between the $\mathrm{SH}_{1}$ and $\mathrm{SH}_{2}$ variables, for the $50 \% \mathrm{nF} 1$ ', $\mathrm{PC1}$ ', PC5' and $\mathrm{NC}^{\prime}$ ' groups (ANOVA repeated-measures, $\mathrm{p}<0.05)$.

Fig. 2 shows the comparison of the groups using the percentage surface microhardness recovery (\%SMHR) variable. Differences were observed between groups $(p<0.05)$. The PC groups presented the best remineralization values, indicating the same pattern observed for the $\mathrm{SH}_{2}$ variable. The $50 \% \mathrm{nF} 1$ ' and $100 \% \mathrm{nF} 5$ 'performances were similar to the PC groups ( 1 ' and $5^{\prime}$ '). No remineralization recovery was detected in the negative control ( 1 or 5 minutes) or in the $50 \%$ nF5' groups.

\section{DISCUSSION}

Studies in the field of cariology have fostered progress in the treatment of dental caries ${ }^{29}$. Nano-scale drug delivery systems have gained ground in this respect and nanotechnology has been investigated as a means to enhance fluoride substantivity in the oral environment ${ }^{13,30,31}$, prolonging its effect with a small amount of product ${ }^{32-34}$. Thus, nano-encapsulated fluoride systems may constitute a promising 


\section{Table 2: Mean and standard deviation (SD) of $\mathrm{SH}_{0}, \mathrm{SH}_{1}$ and $\mathrm{SH}_{2}$ variables of all the groups, according to the different treatment times (one and five minutes).

\begin{tabular}{|c|c|c|c|}
\hline GROUPS & $\mathrm{SH}_{0}(\mathrm{SD})^{*}$ & $\mathrm{SH}_{1}(\mathrm{SD})^{*}$ & $\mathrm{SH}_{2}(\mathrm{SD})^{\star}$ \\
\hline $50 \% \mathrm{nF} 1$ & $432.9(24.36)^{a, A}$ & $17.51(1.67)^{\mathrm{a}, \mathrm{B}}$ & $25.54(5.4)^{\mathrm{a}, \mathrm{c}}$ \\
\hline $50 \%$ nF 5 & $391.56(14.16)^{a, A}$ & $28.69(0.84)^{a, B}$ & $25.86(1.27)^{a, B}$ \\
\hline $100 \% \mathrm{nF} 1$ & $438.64(16.18)^{a, A}$ & $15.23(1.79)^{a, B}$ & $14.5(3.49)^{\mathrm{b}, \mathrm{B}}$ \\
\hline $100 \% \mathrm{nF} 5$ & $390.36(12.31)^{a, A}$ & $25.12(4.33)^{a, B}$ & $27.48(2.88)^{a, B}$ \\
\hline PC 1' & $433.79(28.8)^{a, A}$ & $16.07(0.86)^{a, B}$ & $24.74(0.98)^{\mathrm{a}, \mathrm{C}}$ \\
\hline PC 5' & $390.00(12.85)^{a, A}$ & $29.31(4.93)^{a, B}$ & $36.16(4.57)^{\mathrm{c}, \mathrm{C}}$ \\
\hline NC 1' & $439.42(19.86)^{\mathrm{a}, \mathrm{A}}$ & $16.50(4.46)^{a, B}$ & $14.25(2.1)^{b, B}$ \\
\hline NC 5' & $394.13(7.43)^{a, A}$ & $28.03(5.62)^{a, B}$ & $15.46(3.32)^{b, c}$ \\
\hline
\end{tabular}

*Similar lowercase letters represent no significant difference between groups for each column (ANOVA, $p>0.05)$. Different capital letters represent significant difference within the same group, for each line, for different analyses (ANOVA repeated measures, $p<0.05$ ).

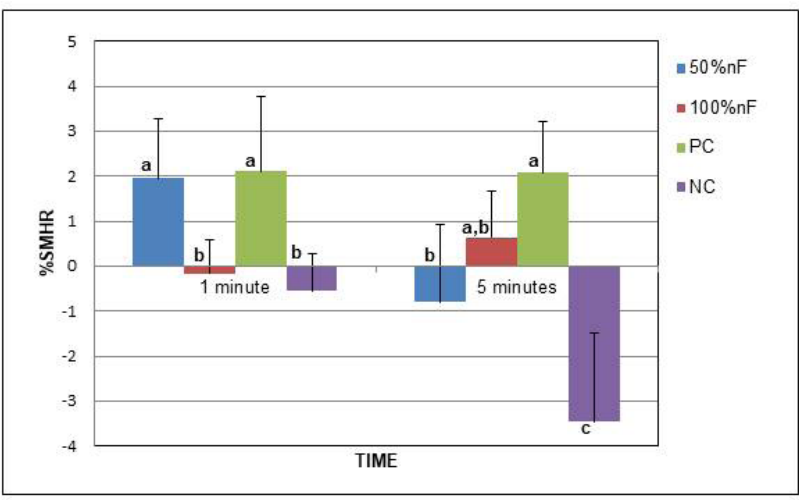

Fig. 2: Mean and standard deviation (SD) of \%SMHR for all groups, according to the different treatment times (one and five minutes).

treatment for carious lesions. In the present study, the nano-encapsulated fluoride (NanoF) system was created as an innovative method to act as a controlled release system to increase fluoride substantivity and bioavailability in the oral cavity. The composition of NanoF is basically sodium fluoride $(\mathrm{NaF})$ encapsulated in a natural biopolymer (hydroxypropyl guar) as the drug carrier. Guar gum is a molecular weight carbohydrate polymer derived from the natural seed of the guar plant (Cyamopsis tetragonoloba (L.) Taub). Its particle size is about $200 \mathrm{~nm}$. Fluoride release is not dependent on $\mathrm{pH}$, but on enzymatic trigger (amylase) following a mechanism of stimuli-controlled release, which is why fresh human saliva was added to the $\mathrm{pH}$ cycling model. Also, a previous clinical study ${ }^{35}$, using the same dentifrices, reported a delay in the fluoride release in saliva within the first 60 minutes after brushing and reported that dental biofilm showed a more prolonged incorporation of fluoride ions when compared to conventional $\mathrm{NaF}$ dentifrice ${ }^{35}$.

It was important to study treatment time ( 1 or 5 minutes) because the NanoF controlled-release dentifrices were created to deliver fluoride ions more slowly. As expected, there were differences in the potential for remineralizing carious lesions according to treatment time. Also, as the literature lacks studies involving the same NanoF, we suggested some hypotheses to explain the role of these dentifrices in the process of remineralization of the decayed enamel.

Fluoride is known for its anti-caries and remineralizing action in its free form and at appropriate concentrations, with a high salivary dose-response level ${ }^{36}$. As fluorine is an electronegative element and thus highly reactive, the $\mathrm{pH}$, ionic concentration, and/or the composition of the vehicle may modulate its action ${ }^{36}$. Based on this concept and the similar remineralization values found in the $50 \% \mathrm{nF} 1$ ' and $\mathrm{PC1}$ ' groups, it was evident that the free $\mathrm{NaF}$ was responsible for the initial performance before NanoF had had sufficient time to exert an effect. However, the unsatisfactory remineralizing performance observed for the $50 \%$ $\mathrm{nF}$ group after five minutes of treatment may have been due to the solvation of fluoride. As the release of NanoF occurred gradually, complexation may have occurred between conventional $\mathrm{NaF}$ and the gradually released NanoF, preventing the effective performance of the fluoride in the remineralization process. Thus, it can be said that the $50 \% \mathrm{nF} 5$, dentifrice behaved similarly to a dentifrice with a low fluoride content. 
Analysis of the $100 \% \mathrm{nF}$ groups showed that the double molecular polymer of the NanoF required a longer treatment time to release fluoride ions more effectively. During the one-minute treatment, the dentifrice resulted in the absence of protective/ remineralizing action. However, an increase of about $75 \%$ in $\%$ SMHR was found for the fiveminute treatment, indicating the importance of the time factor for the release of NanoF. No significant difference was found between the $100 \% \mathrm{nF} 5$ ' and PC groups, despite the lower value for $\%$ SMHR.

A higher concentration of fluoride increases its capacity to diffuse through biofilm and exert an effect on the dental surface, promoting a gain in remineralizing capacity ${ }^{37}$. Nevertheless, a low concentration of fluoride may promote remineralization, provided that it is employed in an acidic vehicle $35,38,39$. Thus, the poor remineralization found in the $50 \% \mathrm{nF} 5$ ' and $100 \% \mathrm{nF} 1$ ' groups may also be explained by the neutral $\mathrm{pH}$ of the dentifrices used. Treatment time, an acidic environment, and sites of

\section{DECLARATION OF CONFLICTING INTERESTS}

The authors declared no potential conflicts of interest with respect to the research, authorship, and/or publication of this article.

\section{FUNDING}

This work was supported in part by a grant from the Institutional Program for Scientific Initiation Scholarships (PIBIC), program of the National Council for Scientific and Technological Development (CNPq) under number 145677/2019-2.

\section{REFERENCES}

1. Paula AB, Fernandes AR, Coelho AS, Marto CM et al. Therapies for White Spot Lesions - A Systematic Review. J Evid Based Dent Pract 2017;17:23-38.

2. Pitts NB, Zero DT, Marsh PD, Ekstrand K et al. Dental Caries. Nat Rev Dis Primers 2017;3:1-16.

3. Buzalaf MAR, Hannas AR, Magalhães AC, Rios D, Honório HM, Delbem AC. pH-cycling models for in vitro evaluation of the efficacy of fluoridated dentifrices for caries control: strengths and limitations. J Appl Oral Sci 2010;18:316-334.

4. Bossù $M$, Saccucci $M$, Salucci A, Giorgio GD et al. Enamel remineralization and repair results of Biomimetic Hydroxyapatite dentifrice on deciduous teeth: an effective option to fluoride dentifrice. J. Nanobiotechnology 2019;17:17.

5. Farooq I, Bugshan A. The role of salivary contents and modern technologies in the remineralization of dental enamel: a narrative review. F1000Res. 2020;9:171.

6. Fontana M. Enhancing Fluoride: Clinical Human Studies greater fluoride concentration are important factors. Promising results were found in a randomized clinical trial using the same experimental dentifrices, which demonstrated an increase in fluoride substantivity, enabling higher concentrations in dental biofilm over time ${ }^{35,38,39}$. When fluoride is presented only in saliva, dilution and swallowing lead to the return to the initial salivary concentration after 40 to 60 minutes of contact with the dentifrice. Thus, the incorporation of fluoride into the biofilm as a reservoir for subsequent release is more desirable for effective remineralization.

A major problem associated with the delivery of fluoride is the short time of action ${ }^{21}$. In the present study, salivary amylase is believed to have broken down the polymer, releasing the nanofluoride for fast, lasting action. Based on these findings, NanoF is a promising nano-encapsulated fluoride system that can be adjusted to promote faster fluoride release, achieve optimal salivary levels, and enable adhesion to biofilm with a prolonged performance.

\section{CORRESPONDENCE}

Dr. Andressa Feitosa Bezerra de Oliveira

Federal University of Paraíba, Health Sciences Center

Campus I, Morphology Department. University Campus University City

Castelo Branco, João Pessoa, Paraíba, Brasil

andressafeitosaboliveira@gmail.com

of Alternatives or Boosters for Caries Management. Caries Res 2016;50:22-37.

7. Danelon M, Pessan JP, Neto FNS, Camargo ER, Delbem ACB. Effect of Toothpaste With Nano-Sized Trimetaphosphate on Dental Caries: In Situ Study. J Dent 2015;43:806-813.

8. Li J, Huang Z, Mei L, Li G, Li H. Anti-Caries Effect of Arginine-Containing Formulations in vivo: A Systematic Review and Meta-Analysis. Caries Res 2015; 49:606-617.

9. Cochrane NJ, Cai F, Huq NL, Burrow MF, Reynolds EC . New Approaches to Enhanced Remineralization of Tooth Enamel. J Dent Res 2010; 89:1187-1197.

10. Ten Cate JM, Buzalaf MAR. Fluoride Mode of Action: Once There Was an Observant Dentist. J Dent Res 2019;98:725730.

11. Walsh CT, Worthington H, Glenny AM, Marinho VC, Jeroncic A. Fluoride Toothpastes of Different Concentrations for Preventing Dental. Cochrane Database Syst Ver. 2019;3:CD007868. 
12. Comar LP, Souza BM, Gracindo LF, Buzalaf MAR, Magalhaes AC. Impact of Experimental Nano-HAP Pastes on Bovine Enamel and Dentin Submitted to a $\mathrm{pH}$ Cycling Model. Braz Dent J. 2013; 24:273-278.

13. Kanduti D, Sterbenk P, Artnik B. Fluoride: a review of use and effects on health. Mater Sociomed 2016;28:133-137.

14. Slade GD, Grider WB, Maas WR, Sanders AE. Water Fluoridation and Dental Caries in U.S. Children and Adolescents. J Dent Res 2018;97:1122-1128.

15. BonettiD,ClarksonJE. FluorideVarnishforCaries Prevention: Efficacy and Implementation. Caries Res 2016;50:45-49.

16. Liang J, Peng X, Zhou X, Zou J, Cheng L. Emerging Applications of Drug Delivery Systems in Oral Infectious Diseases Prevention and Treatment. Molecules 2020;25:129.

17. Moothedath M, Moothedath M, Jairaj A, Harshitha B, Baba SM, Khateeb SU. Role of Nanotechnology in Dentistry: Systematic Review. J Int Soc Prev Community Dent 2019; 9:535-541.

18. AlKahtani RN. The implications and applications of nanotechnology in dentistry: A review. Saudi Dent. J. 2018;30:107-116.

19. Priyadarsin IS, Mukherjee S, Mishra M. Nanoparticles used in dentistry: A review. J Oral Biol Craniofac Res 2018;8:5867.

20. Clarkson BH, Exterkate RAM. Noninvasive Dentistry: A Dream or Reality? Caries Res 2015;49:11-17.

21. Nguyen S, Hiorth M. Advanced drug delivery systems for local treatment of the oral cavity. Ther. Deliv 2015;6:595608

22. European Commission. Commission Recommendation of 18 October 2011 on the definition of nanomaterial. The OJEU. 2011;L275:38-40. URL: https://ec.europa.eu/ research/industrial_technologies/pdf/policy/commission -recommendation-on-the-definition-of-nanomater18102011_en.pdf

23. Li L, Pan H, Tao J, Xu XR, Mao CY, Gu HX, Tang R. Repair of enamel by using hydroxyapatite nanoparticles as the building blocks. J. Mater. Chem 2009;18:4079-4084.

24. Hannig M, Hannig C. Nanomaterials in preventive dentistry. Nat Nanotechnol 2010;5:565-569.

25. Vyavhare S, Sharma D, Kulkarni V. Effect of Three Different Pastes on Remineralization of Initial Enamel Lesion: Anin VitroStudy. Int. J. Clin. Pediatr. Dent. 2015; 39:149-160.

26. Queiroz CS, Hara AT, Paes Leme AF, Cury JA. pH-Cycling models to evaluate the effect of low fluoride dentifrice on enamel De- and remineralization. Braz. Dent. J. 2008;19:2127.

27. Eversole SL, Saunders-Burkhardt K, Faller RV. Erosion protection comparison of stabilised $\mathrm{SnF}$, mixed fluoride active and SMFP/arginine-containing dentifrices. Int Dent J 2014;64:22-28.

28. Vieira A, Delbem ACB, Sassaki KT, Rodrigues E, Cury JA, Cunha RF. Fluoride dose response in $\mathrm{pH}$-cycling models using bovine enamel. Caries Res 2005;39:514-20.

29. Rao R, Jain A, Verma M, Langade D, Patil A. Comparative evaluation of remineralizing potential of Fluoride using three different remineralizing protocols: An in vitro study $\mathbf{J}$ Conserv Dent 2017;20:463-466.

30. Yu OY, Zhao IS, Mei ML, Lo EC, Chu CH. A Review of the Common Models Used in Mechanistic Studies on Demineralization-Remineralization for Cariology Research. Dent J 2017;5: 1-8.

31. Piñón-Segundo E, Mendoza Muñoz N, Quintanar D: Nanoparticles as Dental Drug-Delivery Systems in Nanobiomaterials in Clinical Dentistry. Elsevier 2019; 567593. -URL: https://doi.org/10.1016/B978-0-12-8158869.00023-1

32. Moghadam FV, Pourahmad R, Mortazavi A, Davoodi D, Azizinezhad R. Use of Fish Oil Nanoencapsulated with Gum Arabic Carrier in Low Fat Probiotic Fermented Milk. Food Sci Anim Resour 2019; 39:309-323.

33. Miastkowska M, Lasoń E, Sikora E, Wolińska-Kennard K. Preparation and Characterization of Water-Based NanoPerfumes. Nanomaterials 2018; 8:1-5.

34. Kamaly N, Yameen B, Wu J, Farokhza C O. Degradable Controlled-Release Polymers and Polymeric Nanoparticles: Mechanisms of Controlling Drug Release. Chem. Rev 2016;116: 2602-2663.

35. Moreira VG. Ensaio clínico de biodisponibilidade de fluoretos em dentifrícios com sistema de liberação controlada [master's thesis]. João Pessoa (PB): Federal University of Paraíba;2017. URL: - https://sig-arq.ufpb. br/arquivos/2017209023f1f95260044bf31313ab6a/ Vanderlcia_Gomes_Moreira_DISSERTAO.pdf

36. Øgaard, B. Effects of Fluoride on Caries Development and Progression in vivo. J. Dent. Res. 1990;69:813-819.

37. Mannaa A, Carlén A, Zaura E, Buijs MJ, Bukhary S, Lingström P. Effects of high-fluoride dentifrice $(5,000$ ppm) on caries-related plaque and salivary variables. Clin Oral Investig 2013; 18:1419-1426.

38. Cardoso CAB, Mangueira DFB, Olympio KPK, Rios $\mathrm{D}$ et al. The effect of $\mathrm{pH}$ and fluoride concentration of liquid dentifrices on caries progression. Clin Oral Investig 2014; 18:761-767.

39. Staun Larsen L, Baelum V, Tenuta LMA, Richards A, Nyvad B. Fluoride in saliva and dental biofilm after 1500 and 5000 ppm fluoride exposure. Clin Oral Investig 2017;22:1123-1129. 